\title{
Scenarios for population health inequalities in 2030 in Europe: the EURO-HEALTHY project experience
}

\author{
António Alvarenga ${ }^{1,2,3,4,5}$, Carlos A. Bana e Costa ${ }^{2}$, Carme Borrell ${ }^{6,7}$, Pedro Lopes Ferreira ${ }^{8}$, Ângela Freitas ${ }^{9}$, \\ Liliana Freitas ${ }^{2}$, Mónica D. Oliveira ${ }^{2}$, Teresa C. Rodrigues ${ }^{2}$, Paula Santana ${ }^{9}$, Maria Lopes Santos ${ }^{1}$ and \\ Ana C. L. Vieira ${ }^{2 *}(D)$
}

\begin{abstract}
Background: Health inequalities have been consistently reported across and within European countries and continue to pose major challenges to policy-making. The development of scenarios regarding what could affect population health $(\mathrm{PH})$ inequalities across Europe in the future is considered critical. Scenarios can help policy-makers prepare and better cope with fast evolving challenges.

Objective: This paper describes the three 2030 time-horizon scenarios developed under the EURO-HEALTHY project, depicting the key factors that may affect the evolution of $\mathrm{PH}$ inequalities across European regions.

Methods: A three-stage socio-technical approach was applied: i) identification of drivers (key factors expected to affect the evolution of PH inequalities across European regions until 2030) - this stage engaged in a Web-Delphi process a multidisciplinary panel of 51 experts and other stakeholders representing the different perspectives regarding PH inequalities; ii) generation of scenario structures - different drivers' configurations (i.e. their hypotheses for evolution) were organized into coherent scenario structures using the Extreme-World Method; and iii) validation of scenario structures and generation of scenario narratives. Stages ii) and iii) were conducted in two workshops with a strategic group of 13 experts with a wide view about PH inequalities. The scenario narratives were elaborated with the participants' insights from both the Web-Delphi process and the two workshops, together with the use of evidence (both current and future-oriented) on the different areas within the PH domain.

Results: Three scenarios were developed for the evolution of PH inequalities in Europe until 2030: 'Failing Europe' (worstcase but plausible picture of the future), 'Sustainable Prosperity' (best-case but plausible picture of the future), and an interim scenario 'Being Stuck' depicting a 'to the best of our knowledge' evolution. These scenarios show the extent to which a combination of Political, Economic, Social, Technological, Legal and Environmental drivers shape future health inequalities, providing information for European policy-makers to reflect upon whether and how to design robust policy solutions to tackle $\mathrm{PH}$ inequalities.
\end{abstract}

Conclusions: The EURO-HEALTHY scenarios were designed to inform both policy design and appraisal. They broaden the scope, create awareness and generate insights regarding the evolution of PH inequalities across European regions.

Keywords: Health inequalities, Population Health, Participatory approach, Delphi method, Foresight, Policies, Sociotechnical approach, Scenarios, Stakeholders

\footnotetext{
* Correspondence: ana.lopes.vieira@tecnico.ulisboa.pt

${ }^{2}$ CEG-IST, Centre for Management Studies of Instituto Superior Técnico,

Universidade de Lisboa, Av. Rovisco Pais, 1049-001 Lisbon, Portugal

Full list of author information is available at the end of the article
}

(c) The Author(s). 2019 Open Access This article is distributed under the terms of the Creative Commons Attribution 4.0 International License (http://creativecommons.org/licenses/by/4.0/), which permits unrestricted use, distribution, and reproduction in any medium, provided you give appropriate credit to the original author(s) and the source, provide a link to the Creative Commons license, and indicate if changes were made. The Creative Commons Public Domain Dedication waiver (http://creativecommons.org/publicdomain/zero/1.0/) applies to the data made available in this article, unless otherwise stated. 


\section{Background}

Recognising the importance of health inequalities as a growing policy issue for the European Union (EU), the European Commission [1] issued some key recommendations to the Member States: ". lead on clear and comprehensive strategies to redress the current patterns and magnitude of health inequalities; - ensure the coherence and effectiveness of action to reduce health inequalities at all levels of government and across all sectors and stakeholders; - ensure that the capacities exist for coherent and effective implementation of action on health inequalities; - ensure progressive improvement in the availability and use of data needed to identify priorities, plan action, monitor trends and evaluate what actions are most effective" ([1], p. x). There are however several challenges in the design and implementation of policies for reducing health inequalities, not only on how to assist policy-makers to holistically evaluate policies' benefits and to reflect upon their doability and power issues, but particularly on how to anticipate the extent to which future events may affect those policies $[2,3]$.

The field of foresight and scenario planning offers suitable tools to provide support and advice to policy-makers $[4,5]$ because the key to choose resilient (policy) actions is to define what they should be resilient to [6]. Looking at different plausible scenarios, decision-makers can anticipate possible or potential strategies [7] and use their knowledge to prepare for what may lie ahead, taking a proactive position instead of just accepting the events [8]. Applications of foresight methods to the health context has shown many advantages and offer insights to "be better equipped to improve health systems and interventions, and prepare for future public health incidents" ([9], p. 54). Vollmar and colleagues [10] reviewed 41 papers on the use of scenarios in the health field and concluded that, despite the great potential of scenarios as a strategic decision-making and healthcare planning tool, scenario building methods are not widely used when compared to other methods (e.g. consensus methods, simulation modelling). These authors also found that most published studies do not describe the scenario building process on a transparent and comprehensive way. The reported literature explored issues mainly related with diseases, public health on an organizational level, the healthcare labour market, technology, the pharmaceutical field and aging [10], but up to our knowledge no study has focused on population health $(\mathrm{PH})$ inequalities across European regions.

The EURO-HEALTHY H2020 research project (with EURO-HEALTHY standing for 'Shaping EUROpean policies to promote HEALTH equitY') (2015-2017) [11] proposes a multicriteria Population Health Index (PHI) as a tool to help reflecting upon the future of $\mathrm{PH}$ inequalities and to assist policy evaluation. The development of the PHI was based on the definition of PH by Kindig and Stoddart [12], which acknowledges that accurate measurement of PH must consider the "health outcomes and their distribution within a population, the patterns of determinants that influence such outcomes, and the policies that influence the optimal balance of determinants" ([12], p. 382). Accordingly, the PHI has two components, one regarding health determinants and another regarding health outcomes [13]. Departing from this approach and assuming that scenarios may provide new evidence on possible future developments, the EUROHEALTHY project took the construction of $\mathrm{PH}$ scenarios as a key challenge to inform the evaluation of policies in the context of health inequalities evolution.

A key challenge regarding the scenarios built under the EURO-HEALTHY project was that they needed to be designed in a transparent and replicable way that considered not only the evidence (both current and future-oriented evidence) on the different areas of concern within the domain of $\mathrm{PH}$, but also the diversity of perspectives and values of the full panoply of stakeholders across Europe [14]. This is aligned with literature suggesting that for scenarios to be relevant, consistent and useful, the scenario building process should involve "people whose futures are being discussed are part of the scenario development process" ([8], p. 346). Also, health research has recognised the importance of participatory processes in recent years [15], with a growing understanding that participation of both researchers and stakeholders potentiates dialogue towards health improvements and ways of addressing health inequalities [16-18].

Specifically, this paper describes the EURO-HEALTHY $\mathrm{PH}$ scenarios whose focal issue was the future of $\mathrm{PH}$ inequalities across European regions in 2030. The proposed scenarios aim to support European policy-makers, and the scientific community, to reflect upon what can affect health and health inequalities across European regions in the future, so as to assist policy design and appraisal.

\section{Methods \\ Overview of the socio-technical approach for scenario building}

The goal of our study was to develop PH scenarios able to facilitate European policy-makers' reflection upon what could affect PH inequalities across Europe. Given the wide range of plausible variations in health determinants' inequalities (and on their causal factors) across European regions, an array of possible futures (i.e. scenarios) should be envisaged in order to explicitly consider contextual uncertainty during policy design and appraisal. There are several methodological approaches for building scenarios [19]. Our methodological choice was aligned with the ExtremeWorld Method [20], having in view the advantage of providing a practical and transparent way of establishing plausible boundaries within which the future of $\mathrm{PH}$ inequalities in Europe can unfold. These boundaries are defined by two extreme, yet still plausible, contrasted scenarios, covering 
both the more optimistic (best-case) and the more pessimistic (worst-case) perspectives.

Specifically, the Extreme-World Method [20] was embedded into a three-stage scenario building sociotechnical approach (see Fig. 1). Stage i) Identification of potential drivers' aimed to determine the key factors that were expected to affect the evolution of $\mathrm{PH}$ inequalities across European regions until 2030 (these key factors are called drivers in the scenario terminology). The potential drivers were collected through a Web-Delphi process [21] implemented in the WELPHI Decision Support System [22] that was designed to drive a large multidisciplinary panel of experts and stakeholders, representing a wide range of perspectives regarding $\mathrm{PH}$ inequalities, into the process of identifying drivers relevant to the evolution of $\mathrm{PH}$ inequalities. The potential drivers were generated considering criteria adapted from the Group Elicitation Method (GEM) [23]. In its original application, GEM is a combination of the brain writing technique with a decision support system that allows to depart from an array of viewpoints and reformulate them in a list of concepts by applying different criteria - simplicity, interest, robustness and corroboration [23]. In our adaptation of GEM, the analysts set of number of criteria (see stage i) to then individually perform an individual analysis of the results of the first round of the Web-Delphi process.

Stage ii) 'Validation of drivers and generation of scenario structures' was designed to create two contrasting scenario structures following the Extreme-World Method. For that purpose, a strategic group of 13 members - representing a wide range of perspectives regarding $\mathrm{PH}$ inequalities - participated in a workshop and validated the drivers collected in stage i) (along with the corresponding hypothesis for evolution, called drivers' configurations) and further organized them into two scenario structures: one with all the worst-case (increasing PH inequalities) hypotheses of evolution, and the other with all the best-case (decreasing $\mathrm{PH}$ inequalities) hypotheses.
Stage iii) 'Validation of scenario structures and generation of scenario narratives' kept the workshop format and aimed to adjust and validate the two contrasted scenario structures, as well as to build an interim scenario structure depicting the 'to the best of our knowledge' evolution, in view of giving rise to a reference scenario. The three scenario structures were validated and provided the backbones for the development of scenario narratives to enable a better understanding and communication of the scenarios, which were later enriched with future-oriented evidence that was collected.

Details from the implementation of each stage of the adopted socio-technical approach are described in the following sub-sections.

\section{Stage i) Identification of potential drivers}

A total of 51 experts and other stakeholders were invited to take part of a Web-Delphi process to determine which key factors were expected to affect the evolution of $\mathrm{PH}$ inequalities across European regions until 2030 (the drivers). The participants included people from all over Europe, linked to the public and private sectors and the society at large. Their fields of expertise covered a large spectrum, such as public health, urban and regional planning, social inequalities, environment, and groups at-risk [14]. The Web-Delphi included two rounds: round 1 with open-ended questions for idea-generation regarding the reasons for possible evolutions in PH determinants in Europe; and round 2 for the participants to state their agreement regarding the potential drivers obtained in round 1 .

In round 1, participants were faced with sets of health determinants' indicators (i.e. integrating the health determinants component of the PHI), organized per $\mathrm{PH}$ area of concern (list of indicators within each area of concern provided in Table 2 in Appendix 1), together with their respective performance ranges across regions (reference year 2014; info with reference to the European NUTS 2 regions). For each area of concern, the participants were asked the 'trigger-question': Given the set of current gaps

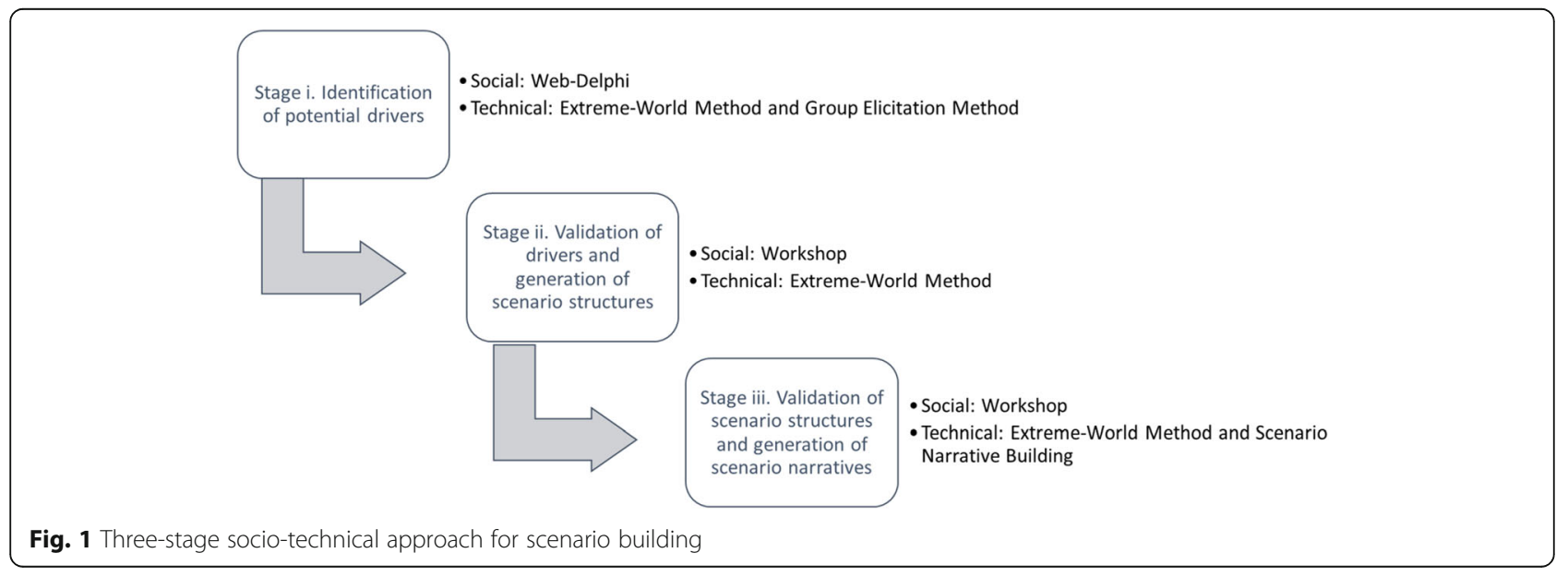


across European regions on the [area of concern] indicators, shown on the left side of your screen, please indicate which of the following three statements do you consider to be plausible (you can select more than one). The options presented (in text boxes) were the following: Until 2030, there will be [an increase, a decrease and/or no change] in [area of concern] inequalities across European regions for the following main reasons. Participants were then invited to opt for a statement of increase, decrease and/or no change on $\mathrm{PH}$ inequalities, and then to provide one or two main reasons for each of those selections. An illustrative example for the area of concern Economic conditions, social protection and security is provided in Figure 4 in Appendix 1. The participants' answers provided a list of potential drivers generated taking into account the following criteria adapted from GEM [23]: (i) address a specific issue, (ii) be nonredundant, (iii) be simple, and (iv) be understandable.

In round 2, participants were presented with the list of potential drivers, organized into six PESTLE categories (Political, Economic, Social, Technological, Legal and Environmental). The PESTLE framework is recognised in the literature as an useful tool to identify key drivers of change in scenario building exercises [24]. For each potential driver, participants had to express their level of agreement regarding its relevance, reacting to the following statement: By itself, this driver can originate a change in population health inequalities until 2030. The answers were given in a fivelevel Likert scale ('Strongly Disagree (SD),' 'Disagree (D), 'Neither Agree nor Disagree (NAD),' 'Agree (A),' 'Strongly Agree (SA)'). Group agreement, which was meant to determine either approval or rejection of any given driver, was analysed by applying specific rules for dealing with differences in opinion. Two rules for approval were established to select drivers (see Table 3 in Appendix 1) and at least one driver from each PESTLE category was included.

\section{Stage ii) Validation of drivers and generation of scenario structures}

A strategic group of 13 experts and stakeholders participated in a first (face-to-face) workshop that targeted the validation of drivers and the development of contrasted, extreme scenario structures. The 13 participants were divided in two groups that worked separately with a coherent sub-set of PESTLE categories and the respective drivers obtained by the end of Stage i). Each group started by discussing the drivers and their configurations - i.e. the worst-case (increasing PH inequalities) and best-case (decreasing PH inequalities) hypotheses of evolution. The discussion resulted in two preliminary scenario structures: one for the worst-case and one for the best-case. The scenario structures' internal consistency was subsequently analysed, and redundancies were eliminated. This workshop ended with the members of the strategic group discussing the results obtained by each sub-group.
Stage iii) Validation of scenario structures and generation of scenario narratives

The strategic group gathered in a second workshop to adjust and validate the two contrasted scenario structures, and to build an interim scenario structure depicting the to the best of our knowledge' evolution, to give rise to a reference scenario. The group discussed the three scenario structures, along with key characteristics for scenarios, such as compatibility, meaningfulness, representativeness and plausibility [19]. To improve the description of each driver configurations - i.e. worst-case (increasing $\mathrm{PH}$ inequalities) and best-case (decreasing PH inequalities) - futureoriented evidence was collected (the search protocol is listed in Table 5 in Appendix 2) and a file with all the information was systematized for each driver. This file can be made available from authors upon request. The final task of this stage was the generation of scenario narratives and the development of factsheets describing each one of the three EURO-HEALTHY PH scenarios. The scenario structures previously validated in the second workshop provided the backbones for these narratives, with the future-oriented evidence being also used to enrich each storyline.

\section{Results}

Analysing the results from the Web-Delphi round 1, five types of answers were identified: answers containing reasons for an increase in $\mathrm{PH}$ inequalities, for a decrease, and for no change; justifications for the 'Don't know/Don't want to answer' option; and additional comments left by participants during the process. These resulted in 362 answers collected, with 240 of these enabling the extraction of drivers - Fig. 2 presents the distribution of the 240 answers by area of concern and by type of answer.

The scrutiny of the 240 answers led to 178 drivers (see Table 4 in Appendix 1) that were included in the WebDelphi round 2. The application of the selection rules defined (see Table 3 in Appendix 1) resulted in 49 drivers (see Table 4 in Appendix 1, drivers highlighted in bold). Then, the generation of scenario structures and the analysis of consistency during the workshops led to 36 drivers, which were plausible and coherent in the framework of the three scenario structures (stages ii) and iii) described above).

Table 1 presents the 36 drivers and corresponding configurations for each scenario structure, organised by PESTLE category: Political (seven drivers), Economic (10 drivers), Social (10 drivers), Technological (one driver), Environmental (seven drivers) and Legal (one driver). The worst-case scenario structure gathers the configurations that, once combined, describe a (plausible) increase in $\mathrm{PH}$ inequalities. On the opposite, the best-case scenario structure, gathers combinations leading to a (plausible) decrease in $\mathrm{PH}$ inequalities. The interim structure, defined as 'to the best of our knowledge' structure, contains the hypothesis that 


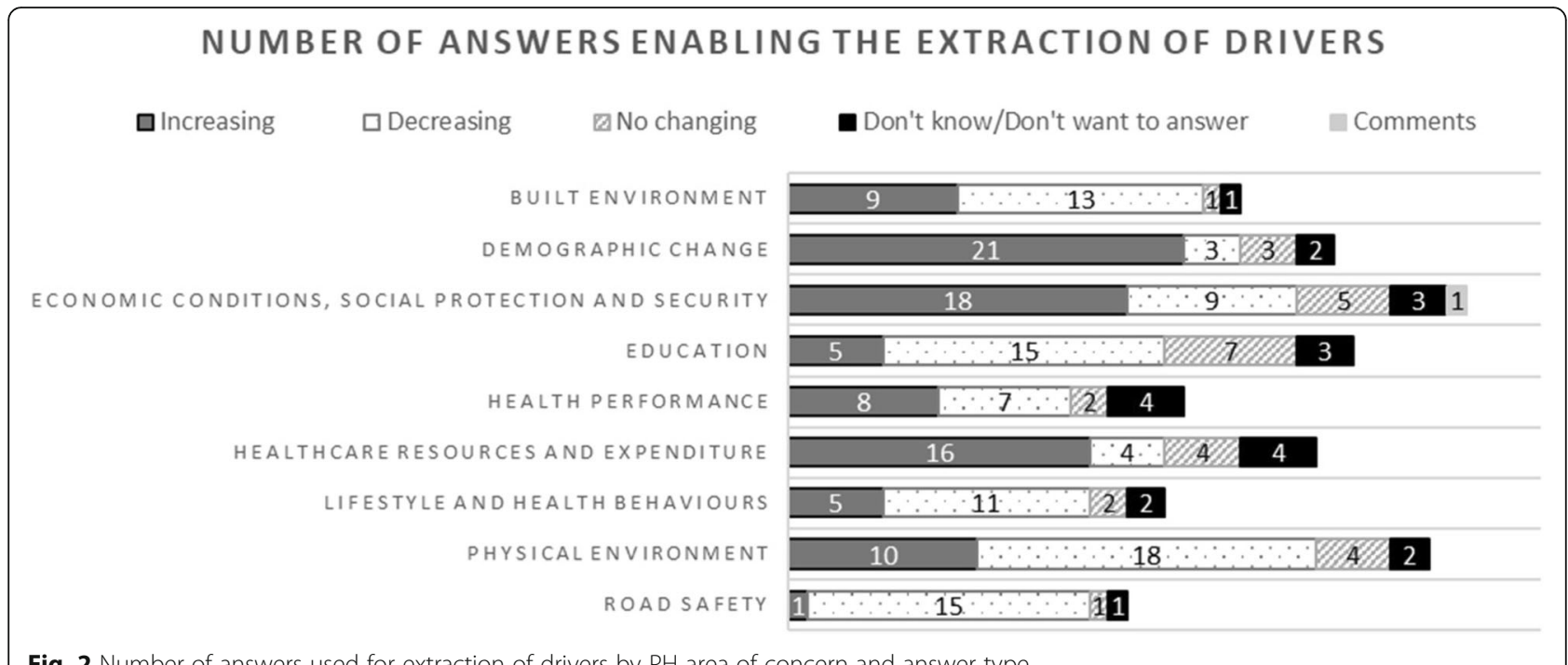

Fig. 2 Number of answers used for extraction of drivers by PH area of concern and answer type

participants expect to happen given the current trends and the available information to this day.

Out of these driver's configurations, three scenarios were constructed and supported by a narrative and storyline. A short symbolic description containing a set of key ideas and the structure for the worst-case scenario 'Failing Europe' (Fig. 3a) and the best-case scenario 'Sustainable Prosperity' (Fig. 3b) were also developed as a result of the process.

\section{Discussion}

\section{The EURO-HEALTHY scenario narratives}

This paper presents the scenarios for the future of $\mathrm{PH}$ inequalities across European regions, for the 2030 time-horizon, developed under the EURO-HEALTHY project. Up to our knowledge these are the first $\mathrm{PH}$ scenarios that focus on $\mathrm{PH}$ inequalities across European regions, hence it is not possible to compare them with other scenario building exercises. However, it should be noted that (a) previous research has recognized there is a large number of determinants of inequalities in health [25], which is aligned with the EUROHEALTHY scenarios' complexity; and (b) some of the EURO-HEALTHY scenario drivers were also captured in four other large public health scenario studies [3, 26-28].

Two highly contrasted scenarios ('Failing Europe' and 'Sustainable Prosperity') and one reference scenario ('Being Stuck') are now outlined and discussed in the light of health inequalities in Europe in 2030. The 'Failing Europe' scenario - the worst-case scenario - assumes an increase in inequalities, whereas 'Sustainable Prosperity' corresponds to the best-case scenario structure, which includes all the configurations that lead to a decrease in $\mathrm{PH}$ inequalities. The reference scenario 'Being Stuck', corresponds to a narrative reflecting the "to best of our knowledge". To comprehensively capture the discussion being conducted it is necessary that the reader of this paper positions her/himself in the future, as in the style of scenario literature. Furthermore, it is important that the reader bears in mind that the scenarios narratives were built departing from the scenario structures developed (the scenario backbones), together with the insights coming from both the Delphi participants (informed by current evidence on $\mathrm{PH}$ inequalities) and the strategic group discussions in the two workshops (informed by both current and future-oriented evidence). Our expectation is that both the scenario narratives content and the exercise of reading the scenarios while being in the future offer insights on key drivers of $\mathrm{PH}$ inequalities which are relevant to inform European health stakeholders and policymakers.

The text that follows describes what will be the future of $\mathrm{PH}$ inequalities across European regions, for the 2030 time-horizon, considering each one of the three EURO-HEALTHY scenarios and all the evidence gathered along the scenario building process.

\section{'Failing Europe' Scenario}

In 2030, Europe plunged into a new, deeper, and longlasting economic crisis. The already difficult situation is being amplified by the refugees' situation, which it is not only far from being solved: it has deteriorated over recent years. The impacts on people's lives are very negative with the increase of inequalities and limited access to basic services such as healthcare. With the social and economic challenges rising every day, other urgent issues such as tackling climate change, have been given second priority, exacerbating the already very serious impacts of the fragmented and ineffective laws and agreements that have been introduced over the last decade. Europe is no longer the solid, strong old continent that we were used to: connection and cohesion gave way to fragmentation. 
Table 1 Overview of the three scenario structures, composed by drivers and drivers' configurations

\begin{tabular}{|c|c|c|c|c|}
\hline PESTLE category & Drivers & $\begin{array}{l}\text { Worst-case } \\
\text { (increase in } \\
\text { inequalities) }\end{array}$ & $\begin{array}{l}\text { To the best of } \\
\text { our knowledge }\end{array}$ & $\begin{array}{l}\text { Best-case } \\
\text { (decrease in } \\
\text { inequalities) }\end{array}$ \\
\hline \multirow[t]{7}{*}{ Political } & $\begin{array}{l}\text { Cohesion funds (or other funds) for less-favoured } \\
\text { regions }\end{array}$ & Reduction & Maintaining & Maintaining \\
\hline & $\begin{array}{l}\text { Political commitment and public support towards } \\
\text { universal access to healthcare }\end{array}$ & Weak & Weak & Strong \\
\hline & Public expenditure in the healthcare system & Reductions & $\begin{array}{l}\text { Priority with often } \\
\text { insufficient funding }\end{array}$ & Increases \\
\hline & Social protection policies for the elderly & Significantly weaker & Significantly weaker & Significantly stronger \\
\hline & Investments in national social security systems & Significantly lower & $\begin{array}{l}\text { Without significant } \\
\text { change }\end{array}$ & Significantly higher \\
\hline & Extent of compulsory education & $\begin{array}{l}\text { Limited and } \\
\text { non-harmonized }\end{array}$ & $\begin{array}{l}\text { Extension with weak } \\
\text { harmonization }\end{array}$ & $\begin{array}{l}\text { Throughout the EU and } \\
\text { increasingly harmonized }\end{array}$ \\
\hline & Quality of Public Education & Decrease & $\begin{array}{l}\text { A priority with often } \\
\text { insufficient funding }\end{array}$ & Increase \\
\hline \multirow[t]{10}{*}{ Economic } & Healthcare efficiency & Significant decrease & $\begin{array}{l}\text { Without significant } \\
\text { change }\end{array}$ & Significant increase \\
\hline & Financial, Economic and Social crises & Deeper and long lasting & Occasional and regular & $\begin{array}{l}\text { Mitigated cyclical global } \\
\text { crises }\end{array}$ \\
\hline & People's material deprivation & Increase & Small decrease & Significant decrease \\
\hline & Economic inequalities & Increase & Increase & Decrease \\
\hline & Social Insurance Schemes & Weakening & Without significant change & Strengthening \\
\hline & Unemployment rate in Europe & Significantly higher & Without significant change & Significantly lower \\
\hline & Long-term structural unemployment & Significant growth & $\begin{array}{l}\text { Without significant } \\
\text { change }\end{array}$ & Significant decrease \\
\hline & Unemployment among 55+ & Significant increase & Significant increase & Decrease \\
\hline & Employment precariousness & Significant increase & Small increase & Decrease \\
\hline & Employment with low income & Significant increase & Small increase & Decrease \\
\hline \multirow[t]{10}{*}{ Social } & $\begin{array}{l}\text { Concentration of people at of poverty and social } \\
\text { exclusion }\end{array}$ & Higher & Higher & Lower \\
\hline & $\begin{array}{l}\text { Medical quality and effectiveness of healthcare } \\
\text { services }\end{array}$ & Deterioration & $\begin{array}{l}\text { Improvements with } \\
\text { many dissimilarities }\end{array}$ & Significantly higher \\
\hline & Access to healthcare & More limited & More limited & Widening \\
\hline & $\begin{array}{l}\text { Quality and accessibility of the primary healthcare } \\
\text { services }\end{array}$ & Significant reduction & Maintaining & Steady growth \\
\hline & $\begin{array}{l}\text { Access and Quality of Emergency Medical Services } \\
\text { (EMS) in remote and/or rural areas }\end{array}$ & Significantly lower & $\begin{array}{l}\text { Without significant } \\
\text { changes }\end{array}$ & Significantly higher \\
\hline & Smoking restriction policies & Softer & Stricter & Stricter \\
\hline & Diet and nutrition & Significantly less healthy & Limited improvement & $\begin{array}{l}\text { Significantly more } \\
\text { healthy }\end{array}$ \\
\hline & Sedentary lifestyles & Increase & Limited reduction & Reduction \\
\hline & $\begin{array}{l}\text { Non-communicable diseases like diabetes and } \\
\text { hypertension }\end{array}$ & Increase & Increase & Decrease \\
\hline & Food security & Compromised & Without significant change & Improved \\
\hline Technological & $\begin{array}{l}\text { Medical innovation (improved and affordable } \\
\text { medicines, medical research and technologies) }\end{array}$ & Stagnation & Slow growth & Rapid growth \\
\hline \multirow[t]{3}{*}{ Environmental } & Quality of the built environment & Decrease & $\begin{array}{l}\text { Without significant } \\
\text { change }\end{array}$ & $\begin{array}{l}\text { Significant } \\
\text { improvement }\end{array}$ \\
\hline & Quality of the natural environment & Decline & Without significant change & Improvement \\
\hline & Quality of the outdoor air & Decline & $\begin{array}{l}\text { Sustain the current } \\
\text { levels }\end{array}$ & Improvement \\
\hline
\end{tabular}


Table 1 Overview of the three scenario structures, composed by drivers and drivers' configurations (Continued)

\begin{tabular}{|c|c|c|c|c|}
\hline PESTLE category & Drivers & $\begin{array}{l}\text { Worst-case } \\
\text { (increase in } \\
\text { inequalities) }\end{array}$ & $\begin{array}{l}\text { To the best of } \\
\text { our knowledge }\end{array}$ & $\begin{array}{l}\text { Best-case } \\
\text { (decrease in } \\
\text { inequalities) }\end{array}$ \\
\hline & Climate change adaptation & Maladaptation & Limited adaptation & $\begin{array}{l}\text { Improved resilient } \\
\text { adaptation }\end{array}$ \\
\hline & Climate change mitigation & Disengagement & Limited action & Engagement \\
\hline & $\begin{array}{l}\text { Priorities in terms of economic model: } \\
\text { green-based vs. fossil fuel-based }\end{array}$ & Fossil fuel-based & Slow transition & Green-based \\
\hline & $\begin{array}{l}\text { Development and penetration of renewable } \\
\text { energy production (water, wind, sun) }\end{array}$ & Slowdown & Increase & $\begin{array}{l}\text { Significant and rapid } \\
\text { increase }\end{array}$ \\
\hline Legal & $\begin{array}{l}\text { EU environmental policies and regulations } \\
\text { (air, water, soil, waste, noise, chemicals) }\end{array}$ & Ineffective & $\begin{array}{l}\text { Limited improvements } \\
\text { in effectiveness }\end{array}$ & Effective \\
\hline
\end{tabular}

Europe's rough ride is very much linked to social and political decisions made over the past 15 years. The weak political commitment and consequent reduction of the funds available to support and help level the European economies are consider holding a significant part of the responsibility for bringing us to this unprecedented crisis. The expression public investment was wiped off the Europe leaders' vocabulary. No one knows the exact moment people stopped being the priority, but the consequences are being felt. People's material deprivation and social exclusion have augmented considerably. And the increasing number of financial and social barriers limits the access to basic services like healthcare services, which raises serious questions regarding, for instance, the increasing number of cases of non-communicable diseases. People are focused on making ends meet and, as some say, 'cannot waste time and money' on keeping healthy lifestyles.

The deeper consequences of an apparently silent enemy, climate change, are also unfolding at a faster pace. The government's inaction towards climate changes, together with the ineffective EU environmental policies and regulations have caused, among others, a decrease in food

\section{a \\ Failing Europe}

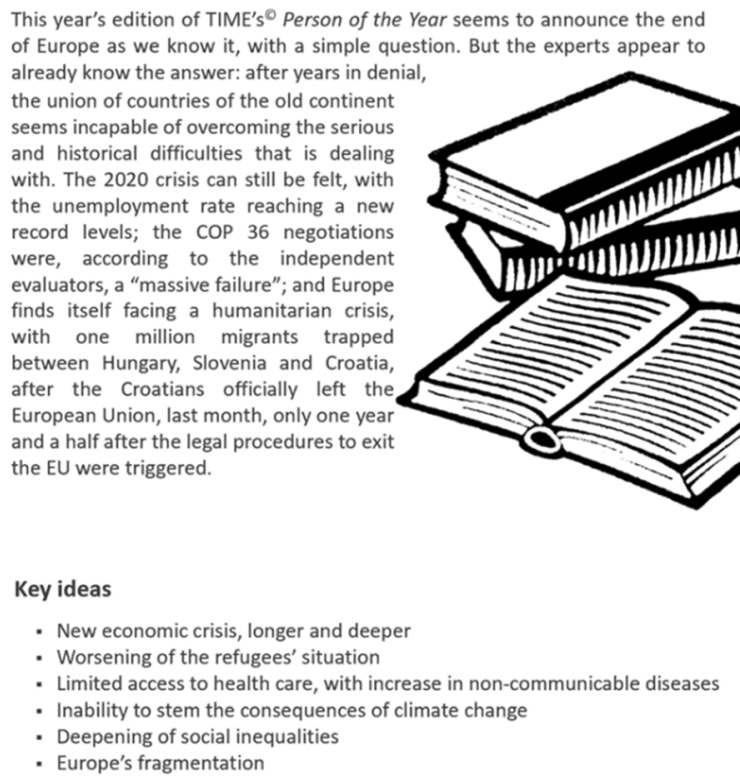

\section{b} Sustainable Prosperity

29 May 2030 The words of the President of the European Commission, last night, at the end of the meeting to present the latest EUROSTAT data, are all over the headlines today. When asked about the great goals achieved in the last 20 years, the President affirmed: "Many compared our objectives, stated after the debate about the future of Europe in 2017 (White Paper on the Future of Europe), to Hercules' Twelve Labours. But just as the hero, we were up to the task. So much things were done that it seems unfair to name only a few. I venture to leave with my Top 3: Europe powered by renewable energies, the lowest unemployment rate ever and HEFA - Health for all - the European program that already ensures free health care services to more than $95 \%$ of the citizens living in Europe."

\section{Key ideas}

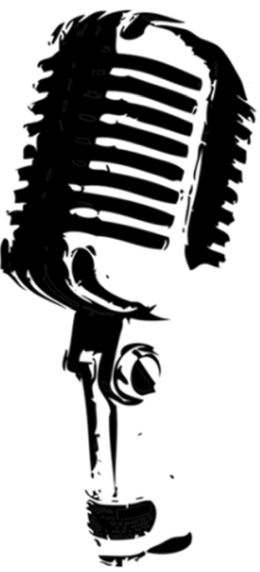

- Investment in the health care system

- Significant improvements on the quality and coverage in Education, in Europe

- Investment in medical innovation

- Establishment of a green-based economy

- Reducing social inequalities

- Decrease in the unemployment rate

- Improved resilient adaptation towards climate change and engagement towards climate change mitigation

Fig. 3 Factsheet for the 'Failing Europe' (a) and 'Sustainable Prosperity' (b) scenarios 
security and availability, translating into an increase of basic food prices. The international disengagement towards climate change mitigation had other consequences, mainly related to the prevalence of a fossil fuel-based economic model: the green, alternative technologies needed today to try to overturn the effects of the maladaptation to climate changes do not exist because the necessary investments were not made at the right time. A new model needs to be settled as soon as possible in order to ensure minimal levels of quality of life for the citizens. This paradigm shift requires workforce to be fulfil. But, throughout Europe, the unemployment rates are significantly higher than 15 years ago, which means that the problem is not the quantity of available workforce. This is an emerging key dilemma of our times: the expertise needed to achieve the goal does not exist and the technology required to leverage and sustain the change in the economic paradigm does not exist or it is not sufficiently developed. Who is to blame? The lack of efforts made to improve and develop the quality of the public education and to harmonize and extent the public compulsory education and the slowdown of the development and penetration of renewable energy technologies might be part of the explanation. Europe stands with its hands tied behind its back. Is it too late now to say sorry?

\section{'Sustainable Prosperity' Scenario}

It is no understatement to claim that Europe "is at its' best". Europe was able to mitigate the cyclical global crises, allowing a reduction of social inequalities in 2030. These important achievements were sustained by the maintenance of funds to help less-favoured regions and through investments in crucial areas such as healthcare and innovation. After the conclusions presented in the White Paper on the Future of Europe [29], in 2017, the European leaders gathered and decided that Europe needed to make partnerships with other economies and companies worldwide and adopt a forward-looking approach, with all the effort that would take: focusing on technological development and people's quality of life allowed to establish a green-based economy and to decrease the unemployment rates. The technology progresses along with the implementation of effective EU environmental policies lead Europe to improve its adaptation towards climate change, "making peace" with both the planet Earth and the European citizens.

The European integration process is alive and delivering. As mentioned, the cyclical global crises were mitigated, and the economic inequalities decreased. The most remarkable and evident consequence of this economic prosperity is the significant decrease in people's material deprivation and in people at risk of poverty, as well as the general improvement in the quality of life. Europe effectively solved the refugees' crisis, something that seemed impossible 15 years ago. The concerns around the longterm sustainability of the healthcare systems and other public services did not block Europe's determination to widen the access to healthcare nor the objective, fully accomplished, to significantly improve the medical quality and effectiveness of healthcare services. The goal to develop better public institutions involved a strong political commitment and implied the reinforcement of investments. The increase of public expenditure in the health system, for instance, was not only responsible for the decrease in non-communicable diseases, like diabetes and hypertension, but also contributed for significantly lower unemployment rates throughout Europe since the systems needed to be reinforced with qualified workforce. The decline of the unemployment rate was also influenced by the commitment to technology development, another goal set in the Europe's bold view of the future. With that vision on one hand and the climate change challenges on the other, European countries made a joint effort towards the development of cutting-edge technologies, capable of enabling a successful transition from a fossil fuel-based paradigm to a Europe powered by renewable energies.

The results exceed the initial expectations: the new green economy, together with effective EU environmental policies and regulations helped mitigating climate change and supported the improvement of the quality of the natural environment, with direct consequences on the food security and on the population's health and lifestyles in general. Europe has been sending a strong and clear message to the world: "old continent" is an outdated nickname. A statement included in the Schuman Declaration of 1950 [30], and recalled in the 2017 White Paper on the Future of Europe [29], can sum up Europe's last decade very well: "Europe will not be made all at once, or according to a single plan. It will be built through concrete achievements which first create solidarity."

\section{'Being stuck' Scenario}

Europe finds itself in a crossroad. In 2030, the envisioned development and the transformation attempts continue to be held by political and economic conditions. The European countries failed to achieve their goals of speeding up the economic growth and create more and better jobs. Few things have changed in the last 15 years. People's economic deprivation experienced a small decrease in general, but economic inequalities increased. People's quality of life did not experience an improvement and old problems are still present problems. It was "now or never" for the European leaders to shape the future of Europe. Did Europe just miss its golden opportunity?

Europe's current situation is the result of a sequence of failed or wasted intentions. After the 2008 economic crisis and the Brexit, Europe seemed to have learned a valuable lesson and the conditions were met to the start of a new era. But the reality turned out to be much more rough and harder to change than expected. One of Europe's main 
challenges was to recover from the economic crisis and regain the citizens' and the world confidence. But the economic growth was slow, and the unemployment rates had no significant changes. The creation of thousands of new jobs seemed feasible: the economic model needed to change and that was the perfect timing to invest and open space for all the unemployed workforce. But the greenmodel economy expansion was slow. Impacts were felt not only in the employment rates but also in the climate change adaptation process: it was limited and far from the objectives set after the Paris Agreement. Despite the governments' engagement, leaders responded too slowly. EU environmental policies were ambitious and experienced a generic improvement in its effectiveness. But those improvements were limited by different interests and financial constraints. The development of renewable energies continued but always pressured by high completion from nonrenewable sources and controlled by budget limitations. Investment was also a problem in other key areas. Insufficient investments in healthcare and social security prevailed, which limited the improvement of the efficiency of these systems; public expenditure in the healthcare system was a priority but the funding was insufficient to tackle all the needs.

Overall, we cannot clearly say that Europe is worse, or better, then 15 years ago. But postponing the resolution of so many major issues puts the old continent in a difficult position. Europe, nowadays (in 2030), is the embodiment of the well-known adage: 'The road to hell is paved with good intentions'.

\section{Strengths and Limitations}

The three-stage socio-technical approach adopted to develop the EURO-HEALTHY scenarios proved to be a transparent and meaningful approach, enabling a multidisciplinary and multidimensional understanding on how the future of PH in Europe may unfold. The combination of both the Web-Delphi process and the workshops allowed answering the technical challenges of identifying a list of drivers together with their hypotheses for evolution. The views and perspectives of a diverse and geographically dispersed group of experts, stakeholders and policy-makers are crucial in the process of scenarios building. In fact, this not only contributes for their validity but particularly meets the challenge of enhancing participation in scenario building. Furthermore, the scenarios proved to be plausible, relevant and showed a new and original perspective on $\mathrm{PH}$ inequalities. As an example, the two contrasted scenarios (best-case and worst-case) were applied to the EUROHEALTHY Lisbon case-study, in which a panel of local stakeholders engaged in a participatory process of policy appraisal and prioritization of policies with potential to promote $\mathrm{PH}$ and decrease inequalities at the city level in light of the $\mathrm{PH}$ scenarios (more details can be found in
[31]). The importance of having a reference scenario (the 'to the best of our knowledge' scenario) was also acknowledged given that in some policy contexts it may help people reflect on what is politically and economically realistic and most likely to occur, therefore boosting their critical reflection around the more extreme-case scenarios. As noted by Wack [32], a 'business as usual' scenario "build on the implicit views of the future shared by most managers, making it possible for them to recognize their outlook in the scenario package." (p. 71). Our reference 'to the best of our knowledge' scenario, although different from a classic 'business as usual' scenario - because it acknowledges expected change (i.e. it does not imply a simple continuation of past trends and structural stability) - shares with the 'business as usual' conception the self-recognition quality highlighted by Wack. Of course, this can only happen when the reference scenario is framed, in the scenario building process, by other contrasted plausible scenarios, as it is the case in both our project and in the classic Shell case, avoiding the dangers of a single future consideration, as also reported by Wack [33].

There are limitations in the process of developing scenarios that should be considered and that go beyond the time-consuming and work-intensity issues. In addition to a subjective assessment and evaluation of complex facts, the type of scenarios depends greatly on the information basis provided and the imagination and background of the experts and other parties involved [34].

\section{Conclusions}

The EURO-HEALTHY scenarios provide information on the most likely future development of health inequalities in Europe in light of the identified drivers. These follow the model structure designed within the PHI framework, defined a priori in 2015. New realities posing challenges to European cohesion, such as the growing mistrust on EU institutions, the cultural conflict over the refugee crisis and migrant influx, the rise of populist movements and terrorism, were not explicitly identified as key drivers affecting the future of health inequalities. Nevertheless, greater attention should be paid to these aspects, linked to the present social and political context, as they potentially affect the drivers selected in this study.

The scenario building process proved to be a transparent and replicable approach to produce substantively meaningful scenarios, with the participants in the process recognising its value and validating the scenarios developed. Hence, the scenarios obtained can be considered as a tool for European policy makers to have a better understanding about plausible future developments of $\mathrm{PH}$, preparing them to counteract increases in inequalities. 


\section{Appendix 1}

\section{Identification of drivers}

Table 2 Indicators used in Web-Delphi round 1, by area of concern of the EURO-HEALTHY Population Health Index

\begin{tabular}{|c|c|}
\hline Area of concern & Indicator \\
\hline \multirow{7}{*}{$\begin{array}{l}\text { Economic conditions, social protection and } \\
\text { security }\end{array}$} & Unemployment rate (\%) \\
\hline & Long-term unemployment rate - 12 months and more (\%) \\
\hline & Disposable income of private households per capita (Euro per inhabitant) \\
\hline & People at risk of poverty or social exclusion (\%) \\
\hline & Disposable income ratio - S80/S20 (ratio) \\
\hline & Expenditure on care for elderly (\% of GDP) \\
\hline & Crimes recorded by the police per 100000 inhabitants \\
\hline \multirow[t]{2}{*}{ Education } & Population aged 25-64 with upper secondary or tertiary education attainment (\%) \\
\hline & Early leavers from education and training (\%) \\
\hline \multirow[t]{2}{*}{ Demographic change } & At risk of poverty rate of older people - aged 65 years or over (\%) \\
\hline & Ageing index (ratio) \\
\hline \multirow[t]{4}{*}{ Lifestyle and Health behaviours } & Adults who are obese (\%) \\
\hline & Daily smokers - aged 15 and over (\%) \\
\hline & Pure alcohol consumption - aged 15 and over (Liters per capita) \\
\hline & Live births by mothers under age of 20 (\%) \\
\hline \multirow[t]{5}{*}{ Physical environment } & Annual mean of the daily PM2.5 concentrations $\left(\mu \mathrm{g} / \mathrm{m}^{3}\right)$ \\
\hline & Annual mean of the daily PM10 concentrations $\left(\mu \mathrm{g} / \mathrm{m}^{3}\right)$ \\
\hline & Greenhouse $\mathrm{Gas}(\mathrm{GHG})$, total tonnes of $\mathrm{CO}_{2}$ eq. emissions per annum per capita \\
\hline & Population exposed to traffic noise - Lden 55-59db, during day (\%) \\
\hline & Population affected by flooding, per 1000000 inhabitants \\
\hline \multirow[t]{7}{*}{ Built environment } & Average number of rooms per person \\
\hline & Households without indoor flushing toilet (\%) \\
\hline & Households without central heating (\%) \\
\hline & Population density (inhabitants $/ \mathrm{km}^{2}$ ) \\
\hline & Population connected to public water supply (\%) \\
\hline & Population connected to wastewater treatment plants (\%) \\
\hline & Recycling rate of municipal waste (\%) \\
\hline \multirow[t]{2}{*}{ Road safety } & Victims in road accidents - injured and killed, per 100000 inhabitants \\
\hline & Fatality rate due to road traffic accidents, per 1000 victims \\
\hline \multirow[t]{5}{*}{ Healthcare resources and expenditure } & Medical doctors, per 100000 inhabitants \\
\hline & $\begin{array}{l}\text { Health personnel (nurses and midwives, dentists, pharmacists and physiotherapists), per } 100000 \\
\text { inhabitants }\end{array}$ \\
\hline & Total health expenditure (THE), PPP\$ per capita, World Health Organization (WHO) estimates \\
\hline & Private households' out-of-pocket on health as percentage of total health expenditure (THE) \\
\hline & Public expenditure on health, PPP\$ per capita, WHO estimates \\
\hline \multirow[t]{2}{*}{ Healthcare performance } & Hospital discharges due to diabetes, hypertension and asthma, per 100000 inhabitants \\
\hline & Amenable deaths to health care - standardised death rate, per 100000 inhabitants \\
\hline
\end{tabular}




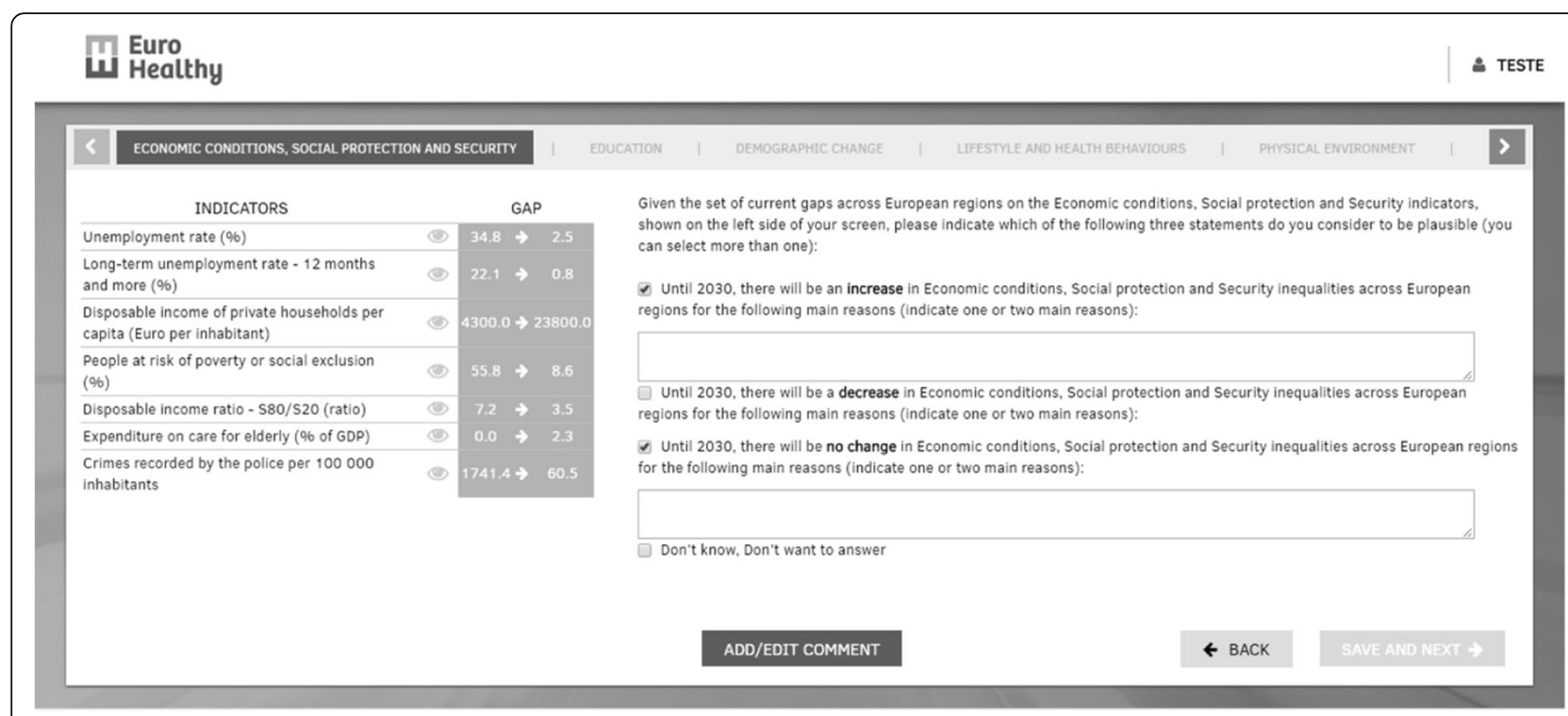

Fig. 4 Print-screen showing the Web-Delphi round 1 questionnaire. Areas of concern of the EURO-HEALTHY PHI are on the top and the respective indicators are on the left. A text box opened when participants selected an option to answer

Table 3 Selection rules applied to the answers of the Web-Delphi round 2 considering the five-level Likert scale: 'Strongly Disagree $(\mathrm{SD})$ ', 'Disagree (D)', 'Neither Agree nor Disagree (NAD)', 'Agree (A)', 'Strongly Agree (SA)'

\begin{tabular}{ll}
\hline Selection rules & Selection rule \\
\hline First rule - applied to all drivers from all PESTLE categories & $(S A+A) \geq \frac{2}{3}$ and SA $\geq \frac{1}{3}$ and (SD + D) $<10 \%$ \\
$\begin{array}{l}\text { Second rule - applied to drivers within the PESTLE categories in which } \\
\text { the first rule did not select any driver }\end{array}$ & $\left[(S A+A) \geq \frac{3}{4}\right.$ or SA $\left.\left.\geq \frac{1}{4}\right)\right]$ and $(S D+D)<10 \%$ \\
\hline
\end{tabular}


Table 4 List of 178 potential drivers included in round 2 of the Web-Delphi, and distribution of the answers in that round

\begin{tabular}{|c|c|c|c|c|c|c|c|}
\hline PESTLE category & Driver & SD & $\mathrm{D}$ & NAD & A & SA & $\begin{array}{l}\text { DK } \\
\text { DWtA }\end{array}$ \\
\hline Political & Strength of liberal political orientations & $7 \%$ & $7 \%$ & $10 \%$ & $33 \%$ & $38 \%$ & $5 \%$ \\
\hline Political & Capacity to produce EU agreements & & $7 \%$ & $40 \%$ & $48 \%$ & $5 \%$ & \\
\hline Political & EU integration process & & $2 \%$ & $26 \%$ & $55 \%$ & $17 \%$ & \\
\hline Political & Confidence in EU policies & $2 \%$ & $2 \%$ & $43 \%$ & $48 \%$ & $5 \%$ & \\
\hline Political & Cohesion funds (or other funds) for less-favoured regions & & $2 \%$ & $7 \%$ & $43 \%$ & $48 \%$ & \\
\hline Political & $\begin{array}{l}\text { Political commitment and ideological support towards } \\
\text { universal access to healthcare }\end{array}$ & $2 \%$ & $5 \%$ & $10 \%$ & $29 \%$ & $55 \%$ & \\
\hline Political & State involvement in public health & $2 \%$ & $2 \%$ & $12 \%$ & $33 \%$ & $50 \%$ & \\
\hline Political & $\begin{array}{l}\text { Commitment to appropriateness of the healthcare systems in } \\
\text { the EU }\end{array}$ & & $5 \%$ & $31 \%$ & $36 \%$ & $26 \%$ & $2 \%$ \\
\hline Political & $\begin{array}{l}\text { Market oriented reforms in healthcare (including privatization } \\
\text { of healthcare) }\end{array}$ & $7 \%$ & $10 \%$ & $14 \%$ & $31 \%$ & $38 \%$ & \\
\hline Political & Priority for investment in innovation in health & $5 \%$ & $7 \%$ & $14 \%$ & $45 \%$ & $29 \%$ & \\
\hline Political & Social protection policies for the elderly & & $7 \%$ & $5 \%$ & $40 \%$ & $48 \%$ & \\
\hline Political & Investments in national social security systems & $2 \%$ & & $10 \%$ & $48 \%$ & $40 \%$ & \\
\hline Political & $\begin{array}{l}\text { Global political evolution (e.g. the aftermath of the United States } \\
\text { elections; Syria war, etc.) }\end{array}$ & $2 \%$ & $12 \%$ & $26 \%$ & $29 \%$ & $31 \%$ & \\
\hline Political & $\begin{array}{l}\text { Power of populistic, protectionist and nationalist radical political } \\
\text { projects in the EU }\end{array}$ & $5 \%$ & $7 \%$ & $19 \%$ & $29 \%$ & $38 \%$ & $2 \%$ \\
\hline Political & Political stability in the EU and its Member-States (e.g. Brexit) & $2 \%$ & $7 \%$ & $21 \%$ & $50 \%$ & $17 \%$ & $2 \%$ \\
\hline Political & Municipalisation [i.e. power to the municipalities] & $5 \%$ & $10 \%$ & $33 \%$ & $33 \%$ & $17 \%$ & $2 \%$ \\
\hline Political & Application of road regulations/rules & & $10 \%$ & $31 \%$ & $48 \%$ & $2 \%$ & $10 \%$ \\
\hline Political & $\begin{array}{l}\text { Degree of penalization associated with traffic policies to reduce } \\
\text { traffic accidents }\end{array}$ & $2 \%$ & $12 \%$ & $31 \%$ & $38 \%$ & $7 \%$ & $10 \%$ \\
\hline Political & Policies for reducing traffic accidents in Eastern countries & & & $29 \%$ & $48 \%$ & $19 \%$ & $5 \%$ \\
\hline Political & Levels of investment in road safety & & $5 \%$ & $26 \%$ & $48 \%$ & $19 \%$ & $2 \%$ \\
\hline Political & Austerity policies & $7 \%$ & $5 \%$ & $10 \%$ & $31 \%$ & $43 \%$ & $5 \%$ \\
\hline Political & Growth of compulsory education & & $5 \%$ & $7 \%$ & $40 \%$ & $45 \%$ & $2 \%$ \\
\hline Political & Privatization of education & $10 \%$ & $17 \%$ & $19 \%$ & $31 \%$ & $21 \%$ & $2 \%$ \\
\hline Political & Investment in the modernization of the built environment & & $5 \%$ & $21 \%$ & $40 \%$ & $33 \%$ & \\
\hline Economic & $\begin{array}{l}\text { Financing of the healthcare sector (in proportion of the Gross } \\
\text { Domestic Product) in more economically vulnerable countries }\end{array}$ & $2 \%$ & $2 \%$ & $10 \%$ & $55 \%$ & $29 \%$ & $2 \%$ \\
\hline Economic & Social insurance schemes & $2 \%$ & $7 \%$ & $10 \%$ & $40 \%$ & $40 \%$ & \\
\hline Economic & Financial pressure on healthcare systems & $5 \%$ & $7 \%$ & $10 \%$ & $50 \%$ & $29 \%$ & \\
\hline Economic & Public expenditure in the healthcare system & & $2 \%$ & $7 \%$ & $50 \%$ & $40 \%$ & \\
\hline Economic & Healthcare costs & $2 \%$ & $5 \%$ & $17 \%$ & $36 \%$ & $40 \%$ & \\
\hline Economic & Constraints on fiscal policies & & $2 \%$ & $33 \%$ & $43 \%$ & $14 \%$ & $7 \%$ \\
\hline Economic & $\begin{array}{l}\text { Economic evolution in EU countries with a younger population } \\
\text { compared to the economic evolution in EU countries with an } \\
\text { older population }\end{array}$ & & $2 \%$ & $24 \%$ & $55 \%$ & $12 \%$ & $7 \%$ \\
\hline Economic & $\begin{array}{l}\text { Economic growth of some EU countries, namely of the ones } \\
\text { from the former Eastern block }\end{array}$ & $2 \%$ & & $24 \%$ & $64 \%$ & $10 \%$ & \\
\hline Economic & $\begin{array}{l}\text { Evolution of socioeconomic conditions and wealth in less } \\
\text { developed countries/areas in Europe }\end{array}$ & & $2 \%$ & $7 \%$ & $57 \%$ & $31 \%$ & $2 \%$ \\
\hline Economic & Economic evolution (e.g. Gross Domestic Product, productivity) & & $5 \%$ & $24 \%$ & $43 \%$ & $26 \%$ & $2 \%$ \\
\hline Economic & $\begin{array}{l}\text { Economic evolution in some countries of the Southern Europe } \\
\text { (compared to the other EU countries) }\end{array}$ & & $2 \%$ & $17 \%$ & $52 \%$ & $26 \%$ & $2 \%$ \\
\hline Economic & Economic and social crises & & & $5 \%$ & $43 \%$ & $52 \%$ & \\
\hline
\end{tabular}


Table 4 List of 178 potential drivers included in round 2 of the Web-Delphi, and distribution of the answers in that round (Continued)

\begin{tabular}{|c|c|c|c|c|c|c|c|}
\hline PESTLE category & Driver & SD & D & NAD & A & SA & $\begin{array}{l}\text { DK } \\
\text { DWtA }\end{array}$ \\
\hline Economic & Financial crisis & & $2 \%$ & $10 \%$ & $38 \%$ & $50 \%$ & \\
\hline Economic & Concentration of capital accumulation & $2 \%$ & $5 \%$ & $24 \%$ & $36 \%$ & $33 \%$ & \\
\hline Economic & People's economic stress & & $2 \%$ & $14 \%$ & $38 \%$ & $45 \%$ & \\
\hline Economic & Economic inequalities & $2 \%$ & & $2 \%$ & $21 \%$ & $74 \%$ & \\
\hline Economic & $\begin{array}{l}\text { Early retirement in some countries of the Southern Europe } \\
\text { (compared to the other EU countries) }\end{array}$ & & $12 \%$ & $52 \%$ & $26 \%$ & $7 \%$ & $2 \%$ \\
\hline Economic & Pension levels and differences in working after retirement & & $2 \%$ & $19 \%$ & $57 \%$ & $21 \%$ & \\
\hline Economic & Proportion of economically dependent population & & $2 \%$ & $21 \%$ & $45 \%$ & $31 \%$ & \\
\hline Economic & $\begin{array}{l}\text { Evolution of financial burden share between generations } \\
\text { within families }\end{array}$ & & $5 \%$ & $26 \%$ & $45 \%$ & $24 \%$ & \\
\hline Economic & $\begin{array}{l}\text { Financial pressures leading to cuts in social expenditures } \\
\text { (e.g. pensions) }\end{array}$ & & $2 \%$ & $7 \%$ & $40 \%$ & $50 \%$ & \\
\hline Economic & $\begin{array}{l}\text { Differences in pension regimes within the EU (e.g. differences } \\
\text { in national net pension replacement rates) }\end{array}$ & & $2 \%$ & $29 \%$ & $45 \%$ & $21 \%$ & $2 \%$ \\
\hline Economic & Poverty levels & & & $7 \%$ & $21 \%$ & $71 \%$ & \\
\hline Economic & Social benefits & & & $12 \%$ & $43 \%$ & $45 \%$ & \\
\hline Economic & Global economic integration and interrelations & & $7 \%$ & $21 \%$ & $45 \%$ & $21 \%$ & $5 \%$ \\
\hline Economic & Inclusion of the refugees on the labour market & $2 \%$ & $10 \%$ & $21 \%$ & $40 \%$ & $26 \%$ & \\
\hline Economic & Unemployment rate in Europe & & $2 \%$ & $2 \%$ & $48 \%$ & $48 \%$ & \\
\hline Economic & Long-term structural unemployment & & & $2 \%$ & $33 \%$ & $64 \%$ & \\
\hline Economic & Unemployment in late ages & & & $7 \%$ & $43 \%$ & $50 \%$ & \\
\hline Economic & Employment precariousness & & & $2 \%$ & $52 \%$ & $43 \%$ & $2 \%$ \\
\hline Economic & Employment with low income/limited social benefits & & & $7 \%$ & $43 \%$ & $50 \%$ & \\
\hline Economic & $\begin{array}{l}\text { Unemployment in countries of the Southern Europe (compared } \\
\text { to the other EU countries) }\end{array}$ & & $7 \%$ & $21 \%$ & $43 \%$ & $24 \%$ & $5 \%$ \\
\hline Economic & Employment opportunities for people with low qualifications & & $2 \%$ & $17 \%$ & $64 \%$ & $17 \%$ & \\
\hline Economic & Employment opportunities for medical/health personnel & $2 \%$ & $14 \%$ & $29 \%$ & $45 \%$ & $10 \%$ & \\
\hline Economic & Disparities in industry production & & $14 \%$ & $50 \%$ & $24 \%$ & $7 \%$ & $5 \%$ \\
\hline Economic & Investment in formal education & & $2 \%$ & $24 \%$ & $45 \%$ & $29 \%$ & \\
\hline Economic & Demand for qualified workers & & $10 \%$ & $33 \%$ & $48 \%$ & $7 \%$ & $2 \%$ \\
\hline Social & Refugees and migrants' fluxes & & $7 \%$ & $17 \%$ & $60 \%$ & $14 \%$ & $2 \%$ \\
\hline Social & $\begin{array}{l}\text { Migrations to the most economically developed North-West } \\
\text { European countries }\end{array}$ & & $7 \%$ & $26 \%$ & $57 \%$ & $7 \%$ & $2 \%$ \\
\hline Social & $\begin{array}{l}\text { Emigration from EU countries already affected by population } \\
\text { ageing and decrease in natality }\end{array}$ & & $12 \%$ & $26 \%$ & $48 \%$ & $12 \%$ & $2 \%$ \\
\hline Social & Urbanisation (attractiveness of urban areas) & & $7 \%$ & $31 \%$ & $50 \%$ & $12 \%$ & \\
\hline Social & Concentration of people in suburban areas & & $7 \%$ & $33 \%$ & $45 \%$ & $14 \%$ & \\
\hline Social & $\begin{array}{l}\text { Concentration of people at risk (e.g. poverty) in problematic } \\
\text { neighbourhoods }\end{array}$ & & $2 \%$ & $7 \%$ & $48 \%$ & $43 \%$ & \\
\hline Social & $\begin{array}{l}\text { Differential in regions' ability (political and/or economic) to attract } \\
\text { young people, including migrants and refugees }\end{array}$ & & $5 \%$ & $21 \%$ & $55 \%$ & $17 \%$ & $2 \%$ \\
\hline Social & Population ageing & & $14 \%$ & $19 \%$ & $31 \%$ & $36 \%$ & \\
\hline Social & Quantitative evolution of the young population & & $14 \%$ & $36 \%$ & $36 \%$ & $10 \%$ & $5 \%$ \\
\hline Social & Birth rates across EU countries & & $14 \%$ & $43 \%$ & $33 \%$ & $10 \%$ & \\
\hline Social & Birth rates in some countries of the Southern Europe (compared & & $14 \%$ & $45 \%$ & $33 \%$ & $7 \%$ & \\
\hline
\end{tabular}


Table 4 List of 178 potential drivers included in round 2 of the Web-Delphi, and distribution of the answers in that round (Continued)

\begin{tabular}{|c|c|c|c|c|c|c|c|}
\hline PESTLE category & Driver & SD & $\mathrm{D}$ & NAD & A & SA & $\begin{array}{l}\text { DK } \\
\text { DWtA }\end{array}$ \\
\hline Social & $\begin{array}{l}\text { Ageing pace in Central and Eastern Europe compared to } \\
\text { other EU countries }\end{array}$ & & $12 \%$ & $43 \%$ & $40 \%$ & $5 \%$ & \\
\hline Social & Regional differences in ageing patterns at a European level & & $12 \%$ & $40 \%$ & $40 \%$ & $7 \%$ & \\
\hline Social & Life expectancy & & $12 \%$ & $19 \%$ & $43 \%$ & $21 \%$ & $5 \%$ \\
\hline Social & Healthy life expectancy & & $10 \%$ & $17 \%$ & $29 \%$ & $38 \%$ & $7 \%$ \\
\hline Social & Differential in regions' health expectancy & & $7 \%$ & $19 \%$ & $50 \%$ & $17 \%$ & $7 \%$ \\
\hline Social & Voting power of the elderly population & $2 \%$ & $12 \%$ & $60 \%$ & $21 \%$ & $5 \%$ & \\
\hline Social & Population growth in relation to the "housing capacity" & & $7 \%$ & $55 \%$ & $29 \%$ & $5 \%$ & $5 \%$ \\
\hline Social & Awareness of the road safety problematic & & $17 \%$ & $45 \%$ & $31 \%$ & $5 \%$ & $2 \%$ \\
\hline Social & Road safety campaigns and education & $2 \%$ & $10 \%$ & $38 \%$ & $40 \%$ & $7 \%$ & $2 \%$ \\
\hline Social & Social pressure for "bridging the gap" in terms of built environment & & $5 \%$ & $29 \%$ & $62 \%$ & $5 \%$ & \\
\hline Social & Overall quality of road infrastructure & $2 \%$ & $2 \%$ & $31 \%$ & $55 \%$ & $7 \%$ & $2 \%$ \\
\hline Social & Quality of the roads in Southern and Eastern Europe & $2 \%$ & $7 \%$ & $29 \%$ & $52 \%$ & $7 \%$ & $2 \%$ \\
\hline Social & Vehicles quality and safety & & $2 \%$ & $36 \%$ & $50 \%$ & $10 \%$ & $2 \%$ \\
\hline Social & Metropolization & & $2 \%$ & $45 \%$ & $45 \%$ & $5 \%$ & $2 \%$ \\
\hline Social & Traffic density & & $5 \%$ & $38 \%$ & $38 \%$ & $19 \%$ & \\
\hline Social & Disparities in medical standards & & $2 \%$ & $17 \%$ & $43 \%$ & $36 \%$ & $2 \%$ \\
\hline Social & Medical quality & & $5 \%$ & $17 \%$ & $38 \%$ & $40 \%$ & \\
\hline Social & Medical effectiveness of healthcare services & & $2 \%$ & $12 \%$ & $45 \%$ & $40 \%$ & \\
\hline Social & Access to healthcare & & & $5 \%$ & $33 \%$ & $62 \%$ & \\
\hline Social & Access to hospital emergency room & & $5 \%$ & $10 \%$ & $52 \%$ & $33 \%$ & \\
\hline Social & Quality and accessibility of the primary health care services & & & $5 \%$ & $38 \%$ & $57 \%$ & \\
\hline Social & Access to healthcare services in rural areas & & & $10 \%$ & $40 \%$ & $48 \%$ & $2 \%$ \\
\hline Social & $\begin{array}{l}\text { Quality of Emergency Medical Services (EMS) in remote and/or } \\
\text { rural areas }\end{array}$ & & $2 \%$ & $10 \%$ & $50 \%$ & $36 \%$ & $2 \%$ \\
\hline Social & Emergency Medical Services efficiency & & $5 \%$ & $19 \%$ & $45 \%$ & $31 \%$ & \\
\hline Social & European medical network & & $7 \%$ & $36 \%$ & $45 \%$ & $12 \%$ & \\
\hline Social & European citizens' health literacy and collaboration capacity as patients & & & $29 \%$ & $43 \%$ & $29 \%$ & \\
\hline Social & Educational and public health campaigns & & $10 \%$ & $21 \%$ & $43 \%$ & $26 \%$ & \\
\hline Social & Education and training of health professionals & & $10 \%$ & $24 \%$ & $43 \%$ & $24 \%$ & \\
\hline Social & Mobility of health professionals between countries and regions & & $10 \%$ & $36 \%$ & $40 \%$ & $12 \%$ & $2 \%$ \\
\hline Social & Concentration of equipment and clusters of medical activities & & $5 \%$ & $43 \%$ & $36 \%$ & $17 \%$ & \\
\hline Social & Availability of health infrastructures & & $2 \%$ & $19 \%$ & $48 \%$ & $31 \%$ & \\
\hline Social & Coverage of National Health Service & & & $5 \%$ & $52 \%$ & $40 \%$ & $2 \%$ \\
\hline Social & $\begin{array}{l}\text { Response capacity of the health sector (quality of emergency/first } \\
\text { respondents and hospital care) in less developed countries }\end{array}$ & & & $12 \%$ & $55 \%$ & $31 \%$ & $2 \%$ \\
\hline Social & Quality of healthcare organization and management & & $5 \%$ & $10 \%$ & $48 \%$ & $38 \%$ & \\
\hline Social & Knowledge sharing & & $2 \%$ & $33 \%$ & $36 \%$ & $26 \%$ & $2 \%$ \\
\hline Social & Availability of information on better lifestyles & & $5 \%$ & $36 \%$ & $36 \%$ & $24 \%$ & \\
\hline Social & Quality of the education in the EU & & & $17 \%$ & $52 \%$ & $31 \%$ & \\
\hline Social & Academisation of the society & & $7 \%$ & $40 \%$ & $40 \%$ & $10 \%$ & $2 \%$ \\
\hline Social & Low qualifications in the EU & & & $29 \%$ & $64 \%$ & $7 \%$ & \\
\hline Social & Impacts on the quality of jobs and enthusiasm for Tertiary & & & $38 \%$ & $52 \%$ & $5 \%$ & $5 \%$ \\
\hline
\end{tabular}


Table 4 List of 178 potential drivers included in round 2 of the Web-Delphi, and distribution of the answers in that round (Continued)

\begin{tabular}{|c|c|c|c|c|c|c|c|}
\hline PESTLE category & Driver & SD & $\mathrm{D}$ & NAD & A & SA & $\begin{array}{l}\text { DK } \\
\text { DWtA }\end{array}$ \\
\hline Social & Monitoring of education results & & $7 \%$ & $55 \%$ & $36 \%$ & $2 \%$ & \\
\hline Social & $\begin{array}{l}\text { Capacity of Eastern European countries to cope with the } \\
\text { collapse of the soviet society [i.e. with the loss of some of } \\
\text { its key features, for instance in education] }\end{array}$ & & $10 \%$ & $45 \%$ & $38 \%$ & $5 \%$ & $2 \%$ \\
\hline Social & Educational attainment as an aspiration of EU countries & & $10 \%$ & $29 \%$ & $50 \%$ & $7 \%$ & $5 \%$ \\
\hline Social & Objectives in education in the EU & & $5 \%$ & $43 \%$ & $36 \%$ & $14 \%$ & $2 \%$ \\
\hline Social & Levels of education and literacy & & $2 \%$ & $2 \%$ & $69 \%$ & $24 \%$ & $2 \%$ \\
\hline Social & Flexibility of academic curricula in the EU & $2 \%$ & $12 \%$ & $48 \%$ & $31 \%$ & $2 \%$ & $5 \%$ \\
\hline Social & University fees & & $7 \%$ & $40 \%$ & $36 \%$ & $12 \%$ & $5 \%$ \\
\hline Social & Academisation of job profiles & & $14 \%$ & $50 \%$ & $29 \%$ & $2 \%$ & $5 \%$ \\
\hline Social & Existence of vocational training & & $10 \%$ & $36 \%$ & $43 \%$ & $7 \%$ & $5 \%$ \\
\hline Social & Differences in cultural traditions & & $19 \%$ & $31 \%$ & $36 \%$ & $10 \%$ & $5 \%$ \\
\hline Social & Globalization of style life & & $17 \%$ & $31 \%$ & $43 \%$ & $5 \%$ & $5 \%$ \\
\hline Social & Awareness regarding the impact of lifestyles on quality of life & & $14 \%$ & $17 \%$ & $50 \%$ & $14 \%$ & $5 \%$ \\
\hline Social & Stress & & $7 \%$ & $17 \%$ & $33 \%$ & $40 \%$ & $2 \%$ \\
\hline Social & Awareness campaigns tackling alcohol consumption & & $12 \%$ & $12 \%$ & $52 \%$ & $24 \%$ & \\
\hline Social & Awareness regarding the impact of smoking & & $10 \%$ & $14 \%$ & $48 \%$ & $29 \%$ & \\
\hline Social & Smoking restriction policies & & $2 \%$ & $2 \%$ & $48 \%$ & $48 \%$ & \\
\hline Social & Smoking among women & & & $12 \%$ & $40 \%$ & $48 \%$ & \\
\hline Social & Smoking among manual workers & & & $14 \%$ & $52 \%$ & $31 \%$ & $2 \%$ \\
\hline Social & Taxation and control of unhealthy food consumption & & $2 \%$ & $10 \%$ & $57 \%$ & $31 \%$ & \\
\hline Social & Diet & & $5 \%$ & $17 \%$ & $38 \%$ & $40 \%$ & \\
\hline Social & Disparities in health behaviours & & $7 \%$ & $10 \%$ & $52 \%$ & $31 \%$ & \\
\hline Social & Sedentary lifestyles & & & $17 \%$ & $43 \%$ & $40 \%$ & \\
\hline Social & $\begin{array}{l}\text { Evolution of Non-communicable diseases like diabetes } \\
\text { and hypertension }\end{array}$ & & $2 \%$ & $10 \%$ & $43 \%$ & $43 \%$ & $2 \%$ \\
\hline Social & Social mobility (change in hierarchies in socio-economic positions) & & $7 \%$ & $14 \%$ & $52 \%$ & $26 \%$ & \\
\hline Social & Motorization in Eastern countries & & $7 \%$ & $45 \%$ & $38 \%$ & $5 \%$ & $5 \%$ \\
\hline Technological & Medical innovation (new medicines and technologies) & & $5 \%$ & $17 \%$ & $45 \%$ & $31 \%$ & $2 \%$ \\
\hline Technological & Technology and medical devices at home & & $10 \%$ & $19 \%$ & $45 \%$ & $24 \%$ & $2 \%$ \\
\hline Technological & Technology and innovation costs in healthcare systems & & $7 \%$ & $17 \%$ & $50 \%$ & $26 \%$ & \\
\hline Technological & Evolution of vehicles batteries' autonomy & & $19 \%$ & $40 \%$ & $31 \%$ & $10 \%$ & \\
\hline Technological & $\begin{array}{l}\text { Knowledge and innovation in technology and materials for road } \\
\text { safety }\end{array}$ & & $10 \%$ & $33 \%$ & $45 \%$ & $7 \%$ & $5 \%$ \\
\hline Technological & Innovation in technology and materials for the built environment & & $10 \%$ & $33 \%$ & $40 \%$ & $14 \%$ & $2 \%$ \\
\hline Technological & Innovation in housing (new forms of housing) & & $14 \%$ & $33 \%$ & $33 \%$ & $14 \%$ & $5 \%$ \\
\hline Technological & $\begin{array}{l}\text { Price of technology and materials for road safety and for the built } \\
\text { environment }\end{array}$ & & $7 \%$ & $38 \%$ & $38 \%$ & $14 \%$ & $2 \%$ \\
\hline Technological & Acceleration in industry development in less developed countries & & $14 \%$ & $33 \%$ & $38 \%$ & $12 \%$ & $2 \%$ \\
\hline Technological & Pace of change in manufacturing in Europe (industry 4.0) & & $14 \%$ & $43 \%$ & $26 \%$ & $12 \%$ & $5 \%$ \\
\hline Technological & Automation of industrial production & & $7 \%$ & $40 \%$ & $33 \%$ & $14 \%$ & $5 \%$ \\
\hline Technological & Internet access & $2 \%$ & $5 \%$ & $33 \%$ & $48 \%$ & $12 \%$ & \\
\hline Environmental & Quality of the living environment & & $2 \%$ & $2 \%$ & $50 \%$ & $45 \%$ & \\
\hline Environmental & Quality of the outdoor air & & $2 \%$ & & $38 \%$ & $60 \%$ & \\
\hline
\end{tabular}


Table 4 List of 178 potential drivers included in round 2 of the Web-Delphi, and distribution of the answers in that round (Continued)

\begin{tabular}{|c|c|c|c|c|c|c|c|}
\hline PESTLE category & Driver & SD & $\mathrm{D}$ & NAD & A & SA & $\begin{array}{l}\text { DK } \\
\text { DWtA }\end{array}$ \\
\hline Environmental & Climate change & & $2 \%$ & $14 \%$ & $43 \%$ & $38 \%$ & $2 \%$ \\
\hline Environmental & Climate change actions and policies & & $5 \%$ & $17 \%$ & $43 \%$ & $33 \%$ & $2 \%$ \\
\hline Environmental & $\begin{array}{l}\text { Concerns related to natural resources efficiency (e.g. energy } \\
\text { efficiency) }\end{array}$ & & $7 \%$ & $26 \%$ & $43 \%$ & $24 \%$ & \\
\hline Environmental & Energy efficiency efforts & & $10 \%$ & $19 \%$ & $52 \%$ & $19 \%$ & \\
\hline Environmental & Recycling: taxation and quotas & & $12 \%$ & $29 \%$ & $45 \%$ & $14 \%$ & \\
\hline Environmental & $\begin{array}{l}\text { Social and political awareness/preoccupation with the physical } \\
\text { environment, namely air and noise conditions }\end{array}$ & & $7 \%$ & $14 \%$ & $55 \%$ & $24 \%$ & \\
\hline Environmental & $\begin{array}{l}\text { Gap in "environmental awareness" between more developed } \\
\text { and less developed countries }\end{array}$ & & $2 \%$ & $24 \%$ & $48 \%$ & $26 \%$ & \\
\hline Environmental & $\begin{array}{l}\text { Priorities in terms of economic model: green-based vs } \\
\text { oil-based (e.g. evolution of the number of environmental } \\
\text { friendly vehicles) }\end{array}$ & & $5 \%$ & $10 \%$ & $45 \%$ & $36 \%$ & $5 \%$ \\
\hline Environmental & $\begin{array}{l}\text { Development of sustainable energy production (water, } \\
\text { wind, sun) }\end{array}$ & & & $21 \%$ & $38 \%$ & $40 \%$ & \\
\hline Environmental & Industrial development sustainability & $2 \%$ & $7 \%$ & $29 \%$ & $38 \%$ & $24 \%$ & \\
\hline Environmental & Regional differences of the building construction boom & & $14 \%$ & $29 \%$ & $52 \%$ & $5 \%$ & \\
\hline Environmental & Coordination of environmental-focused political measures & & $7 \%$ & $21 \%$ & $57 \%$ & $14 \%$ & \\
\hline Environmental & Environmental protection policies focused on industrial manufacturing & & $7 \%$ & $17 \%$ & $57 \%$ & $17 \%$ & $2 \%$ \\
\hline Environmental & Environmental protection policies focused on vehicles circulation & & $5 \%$ & $14 \%$ & $60 \%$ & $19 \%$ & $2 \%$ \\
\hline Environmental & International and worldwide environmental agreements & & $7 \%$ & $14 \%$ & $45 \%$ & $31 \%$ & $2 \%$ \\
\hline Environmental & $\begin{array}{l}\text { United States of America commitment towards the Paris Agreement on } \\
\text { climate change global action }\end{array}$ & & $10 \%$ & $14 \%$ & $48 \%$ & $26 \%$ & $2 \%$ \\
\hline Legal & $\begin{array}{l}\text { EU Legislation/ Directives and its transposition into the legislation of each } \\
\text { country }\end{array}$ & & $10 \%$ & $33 \%$ & $43 \%$ & $10 \%$ & $5 \%$ \\
\hline Legal & $\begin{array}{l}\text { Adaptability of EU regulations (especially inside the Eurozone) to } \\
\text { Member-states specificities }\end{array}$ & & $7 \%$ & $45 \%$ & $33 \%$ & $12 \%$ & $2 \%$ \\
\hline Legal & $\begin{array}{l}\text { Commitment to follow EU directives and World Health Organization } \\
\text { guidelines }\end{array}$ & & $5 \%$ & $19 \%$ & $52 \%$ & $21 \%$ & $2 \%$ \\
\hline Legal & EU legislation / directives on built environment & & $7 \%$ & $21 \%$ & $57 \%$ & $10 \%$ & $5 \%$ \\
\hline Legal & National building construction rules and legislation & & $12 \%$ & $31 \%$ & $40 \%$ & $10 \%$ & $7 \%$ \\
\hline Legal & Differences in road safety national legislation & $2 \%$ & $7 \%$ & $29 \%$ & $55 \%$ & $2 \%$ & $5 \%$ \\
\hline Legal & EU environmental policies and regulations & & $5 \%$ & $17 \%$ & $64 \%$ & $12 \%$ & $2 \%$ \\
\hline Legal & $\begin{array}{l}\text { Requirements of compliance to environmental regulations for market } \\
\text { purposes (e.g. quality of fuel) }\end{array}$ & & $2 \%$ & $24 \%$ & $55 \%$ & $17 \%$ & $2 \%$ \\
\hline Legal & Evolution of intellectual property rights in health & $2 \%$ & $12 \%$ & $43 \%$ & $24 \%$ & $14 \%$ & $5 \%$ \\
\hline Legal & $\begin{array}{l}\text { Impact of the TTIP (Transatlantic Trade and Investment Partnership) project } \\
\text { in the access to the latest advances in medicines, diagnostic tools, and other } \\
\text { life-saving medical technologies }\end{array}$ & $5 \%$ & $5 \%$ & $45 \%$ & $26 \%$ & $17 \%$ & $2 \%$ \\
\hline Legal & Integration of EU labour markets & & $10 \%$ & $38 \%$ & $38 \%$ & $10 \%$ & $5 \%$ \\
\hline
\end{tabular}

SD Strongly Disagree, D Disagree, NAD Neither Agree nor Disagree, A Agree, SA Strongly Agree, DK/DWtA Don't Know/Don't Want to Answer Note: the 49 drivers selected after round 2, by applying the selection rules, are highlighted in bold; among these, in italic, are the drivers that resulted from the application of the second selection rule. 


\section{Appendix 2}

\section{Search protocol to collect future-oriented evidence}

Table 5 Search protocol used to collect future-oriented evidence to inform the scenario building process (March of 2017)

\begin{tabular}{ll}
\hline Sources & European Union (EU) publications, through the EU Bookshop | https://bookshop.europa.eu/en/home \\
& FRESHER project | https://www.foresight-fresher.eu/fresher-project-results/
\end{tabular}

Keywords

Search words combined with drivers' keywords (combinations followed this order): future; forecast; scenario; foresight; prospective [lf the search did not deliver meaningful results, the protocol was extended to searches with Google's Search Engine, using the driver's keywords (or equivalent) + the expression European Union. Search results obtained beyond the Search Protocol were pointed out in the drivers' cards]

Timespan

2012-2017

\section{Abbreviations}

EU: European Union; EURO-HEALTHY: Shaping EUROpean policies to promote HEALTH equitY; PESTLE: Political, Economic, Social, Technological, Legal and Environmental; PH: Population Health; PHI: Population Health Index; WHO: World Health Organization

\section{Acknowledgements}

We would like to thank all the experts and stakeholders that participated in the scenario building process for bringing in their time and knowledge.

\section{Authors' contributions}

MO, CBC and PS outlined scenario development within the EURO-HEALTHY project, which general coordinator was PS. AA, CBC and MO conceptualised this paper research aims and methods and participated in the design of the study; they also supervised AV, LF and MLS in the implementation of the methods; AA, AV and LF conducted data collection and analysis; CB, PLF and TR contributed to decisions regarding the study execution; AA, AV, LF, MLS, $\mathrm{MO}, \mathrm{AF}$ and PS prepared the manuscript. All authors contributed to, read and approved the final manuscript. Authors are presented by alphabetical order.

\section{Funding}

This work is part of the EURO-HEALTHY project (Shaping EUROpean policies to promote HEALTH equitY) and it was supported by the European Union's Horizon 2020 research and innovation programme [Grant Agreement No 643398; 2015-2017].

\section{Availability of data and materials}

All data generated and/or analysed during this study are included in this published article and its additional files. The datasets used and/or analysed during the current study are available from the corresponding author on reasonable request. Anonymised fields will be used to ensure that individual participants are not identified.

\section{Ethics approval and consent to participate}

The study was approved by Centre for Social Studies Ethics Commission (CECES) of the University of Coimbra. All participants were invited and informed about the objective, scope and research design of the Web-Delphi and about the uses of Delphi data within the scope of the EURO-HEALTHY project, and have provided, via email, written consent to participate before being enrolled in the Delphi process.

\section{Consent for publication}

Not applicable. The manuscript does not include details related to any individual person.

\section{Competing interests}

The authors declare that they have no competing interests, whether actual or potential, including any financial, personal or other relationships with other people or organizations.

\section{Author details}

${ }^{1}$ ALVA Research and Consulting, Lisbon, Portugal. ${ }^{2}$ CEG-IST, Centre for Management Studies of Instituto Superior Técnico, Universidade de Lisboa,
Av. Rovisco Pais, 1049-001 Lisbon, Portugal. ${ }^{3} \mathrm{HC}$, Institute of Contemporary History, Universidade NOVA de Lisboa, Lisbon, Portugal. ${ }^{4}$ Nova School of Business and Economics, Universidade NOVA de Lisboa, Campus de Carcavelos, Rua da Holanda 1, 2775-405 Carcavelos, Portugal. ${ }^{5}$ ISEG, Lisbon School of Economics \& Management, Universidade de Lisboa, Lisbon, Portugal. ${ }^{6}$ Agència de Salut Pública de Barcelona, Barcelona, Spain. ${ }^{7}$ CIBER of Epidemiology and Public Health (CIBERESP), Madrid, Spain. ${ }^{8}$ Center for Health Studies and Research (CEISUC), University of Coimbra, Coimbra, Portugal. ${ }^{9}$ Centre of Studies in Geography and Spatial Planning (CEGOT), University of Coimbra, Coimbra, Portugal.

Received: 15 March 2019 Accepted: 7 June 2019

Published online: 25 June 2019

\section{References}

1. European Commission. Health inequalities in the EU — Final report of a consortium. Consortium lead: Sir Michael Marmot: European Commission Directorate-General for Health and Consumers; 2013. https://doi.org/10. 2772/34426.

2. Volkery A, Ribeiro T. Scenario planning in public policy: Understanding use, impacts and the role of institutional context factors. Technol Forecast Soc Chang. 2009;76(9):1198-207.

3. Wepner B, Giesecke S. Drivers, trends and scenarios for the future of health in Europe. Impressions from the FRESHER project. Eur J Futur Res. 2018;6(1):38-48.

4. Meyer R. Comparison of scenarios on futures of European food chains. Trends Food Sci Technol. 2007;18(11):540-5.

5. Misuraca G, Broster D, Centeno C. Digital Europe 2030: Designing scenarios for ICT in future governance and policy making. Gov Inf Q. 2012;29:S121-S31.

6. Mikko D, Raija K, Leena I-S, Seija J. Anticipating Alternative Futures for the Platform Economy. Technol Innov Manag Rev. 2017;7(9):6-16.

7. Gambelli D, Vairo D, Zanoli R. Exploiting Qualitative Information for Decision Support in Scenario Analysis. J Decis Syst. 2010;19(4):407-22.

8. Reed MS, Kenter J, Bonn A, Broad K, Burt TP, Fazey IR, et al. Participatory scenario development for environmental management: A methodological framework illustrated with experience from the UK uplands. J Environ Manag. 2013;128(Supplement C):345-62.

9. Masum H, Ranck J, Singer PA. Five promising methods for health foresight. Foresight. 2010;12(1):54-66.

10. Vollmar HC, Ostermann T, Redaelli M. Using the scenario method in the context of health and health care - a scoping review. BMC Med Res Methodol. 2015;15:10.

11. Santana P, editor. Promoting population health and equity in Europe: from evidence to policy. Coimbra: Imprensa da Universidade de Coimbra; 2017.

12. Kindig D, Stoddart G. What is population health? Am J Public Health. 2003; 93(3):380-3.

13. Santana P, Costa C, Freitas Â, Stefanik I, Quintal C, Bana e Costa C, et al. Atlas of population health in European Union regions. Coimbra: Imprensa da Universidade de Coimbra; 2017.

14. Stefanik I, Freitas Â, Doetsch J, Santana P. Involving key stakeholders in the EURO-HEALTHY. In: Santana P, editor. Promoting population health and equity in Europe: from evidence to policy. Coimbra: Coimbra University Press; 2017. p. 60-3.

15. Orlowski SK, Lawn S, Venning A, Winsall M, Jones GM, Wyld K, et al. Participatory Research as One Piece of the Puzzle: A Systematic Review of 
Consumer Involvement in Design of Technology-Based Youth Mental Health and Well-Being Interventions. JMIR Hum Factors. 2015;2(2):e12.

16. Scott V, Stern R, Sanders D, Reagon G, Mathews V. Research to action to address inequities: the experience of the Cape Town Equity Gauge. Int J Equity Health. 2008;7(1):6.

17. Cargo M, Mercer SL. The value and challenges of participatory research: strengthening its practice. Annu Rev Public Health. 2008;29:325-50.

18. Pauly B, Martin W, Perkin K, van Roode T, Kwan A, Patterson T, et al. Critical considerations for the practical utility of health equity tools: a concept mapping study. Int J Equity Health. 2018;17:48.

19. Amer M, Daim TU, Jetter A. A review of scenario planning. Futures. 2013;46:23-40.

20. Goodwin P, Wright G. Scenario planning: an alternative way of dealing with uncertainty. In: Wiley J, Sons L, editors. Decision Analysis for Management Judgment. 3rd ed; 2004.

21. Linstone HA, Turoff M. Introduction. In: Turoff HALM, editor. The Delphi Method: Techniques and applications. London: Addison-Wesley Publishing Company; 1975. p. 3-12.

22. Welphi. Welphi 2017 [14 Mar 2018]. Available from: https:/www.welphi.com/

23. Boy GA. The group elicitation method for participatory design and usability testing. Interactions. 1997;4(2):27-33.

24. Johnson G, Scholes K, Whittington R. Fundamentals of strategy: Pearson Education; 2009

25. Sundmacher L, Scheller-Kreinsen D, Busse R. The wider determinants of inequalities in health: a decomposition analysis. Int J Equity Health. 2011;10(1):30.

26. Futures IA. Public Health 2030: A Scenario Exploration. Alexandria: Institute for Alternative Futures: 2014

27. Forum WE, editor. Sustainable Health Systems: Visions, Strategies, Critical Uncertainties and Scenarios. Geneva: World Economic Forum; 2013.

28. Hoeymans N, Van Loon A, Van den Berg M, Harbers M, Hilderink H, Van Oers J, et al. A healthier Netherlands: Key findings from the dutch 2014 public health status and foresight report. Bilthoven: National Institute for Public Health and the Environment (RIVM); 2014

29. European Commission S-G. White Paper on the Future of Europe - Reflections and scenarios for the EU27 by 2025. Brussels: Belgium European Commission; 2017.

30. Schuman R. The Schuman Declaration; 1950

31. Bana e Costa C, Freitas L, Oliveira M, Rodrigues T, Vieira A. Devising and testing a novel methodology for the evaluation of policies under European population health scenarios. In: Santana P, editor. Promoting population health and equity in Europe: from evidence to policy. Coimbra: Coimbra University Press; 2017. p. 85-7.

32. Wack P. Uncharted waters ahead. Business Harvard Review. 1985;63(5):73-89.

33. Wack P. Shooting the rapids. Harvard Business Review. 1985;63(6):139-50.

34. Kosow H, Gaßner R. Methods of future and scenario analysis: overview, assessment, and selection criteria: German Development Institute; 2008.

\section{Publisher's Note}

Springer Nature remains neutral with regard to jurisdictional claims in published maps and institutional affiliations.

Ready to submit your research? Choose BMC and benefit from:

- fast, convenient online submission

- thorough peer review by experienced researchers in your field

- rapid publication on acceptance

- support for research data, including large and complex data types

- gold Open Access which fosters wider collaboration and increased citations

- maximum visibility for your research: over $100 \mathrm{M}$ website views per year

At $\mathrm{BMC}$, research is always in progress.

Learn more biomedcentral.com/submissions 